\title{
The Pieniny Klippen Belt in Poland
}

\author{
Jan Golonka, Michał Krobicki, Anna Waśkowska \\ AGH University of Science and Technology, Faculty of Geology, Geophysics and Environmental Protection; \\ al. A. Mickiewicza 30,30-059 Krakow, Poland; e-mail: jgolonka@agh.edu.pl
}

(C) 2018 Authors. This is an open access publication, which can be used, distributed and reproduced in any medium according to the Creative Commons CC-BY 4.0 License requiring that the original work has been properly cited.

Received: 25 January 2018; accepted: 10 February 2018

\begin{abstract}
The Pieniny Klippen Belt in Poland marks the Central Carpathian-North European plate suture zone. The strictly tectonic present-day confines of the Pieniny Klippen Belt are characterized as (sub)vertical faults and shear zones. A strong reduction in the space of the original sedimentary basins took place. The strike-slip-bounded tectonic blocks, thrust units, toe-thrusts and olistostromes are mixed together, resulting in the present-day mélange character where individual tectonic units are difficult to distinguish.

The sedimentary rocks of the Pieniny Klippen Belt were deposited in the paleogeographic realm known as the Alpine Tethys that was divided into two basins separated by the Czorsztyn Ridge. The accretionary prism formed in front of the advancing Alcapa (Central Carpathians) terrane had overridden the Czorsztyn Ridge during the Late Cretaceous-Paleocene. The destruction of the Czorsztyn Ridge supplied huge amounts of coarse-clastic material, including olistoliths, into the Magura Basin during the Late Cretaceous-Paleocene.

The rotation of the Alcapa caused the strike-slip motions which led to the deformation of the previously created nappes and development of the flower structure. Two parallel faults delineate the southern and northern limits of the Pieniny Klippen Belt.

The stops in Sromowce (Macelowa and Sobczański Gorge area) allow the observation of the southern marginal zone of the Pieniny Klippen Belt, the overturned position of the rotated counterclockwise deformed rock as well as the diapiric uplift of the Pieniny rocks in a transpressional strike-slip regime. The Zawiasy (Krościenko area) stop is located in the northern marginal zone (Hulina Unit) of the Pieniny Klippen Belt along the major dextral strike-slip Dunajec Fault.
\end{abstract}

Keywords: Central Carpathians, Pieniny Klippen Belt, North European Platform, Magura Nappe, tectonics, mélange

\section{INTRODUCTION}

The Pieniny Klippen Belt (PKB) is situated at the boundary of the Central and Outer (Flysch) Carpathians (Figs. 1, 2). The term Pieniny Klippen Belt was first used by Neumayr (1871). The geographic part of this name indicates the mountain range in Poland and Slovakia where numerous klippes (klippen) build scenic rocks around the Dunajec River gorge, a prime geotouristic attraction since the $19^{\text {th }}$ century (Golonka \& Krobicki 2007). The "Klippen" are relatively erosion-resistant blocks surrounded by and rising above the less competent rocks, mainly turbiditic sandstones and mudstones (flysch), shales and marls. These blocks were traditionally considered as tectonic slivers while recently the role of olistoliths in formation of klippen belts is strongly emphasized (e.g. Nemčok 1980, Cieszkowski et al. 2009, Golonka et al. 2015, 2017). The present day confines of the Pieniny Klippen Belt are strictly tectonic. They are often characterized as (sub)vertical faults and shear zones, along which a strong reduction in the space of the original sedimentary basins has taken place. 


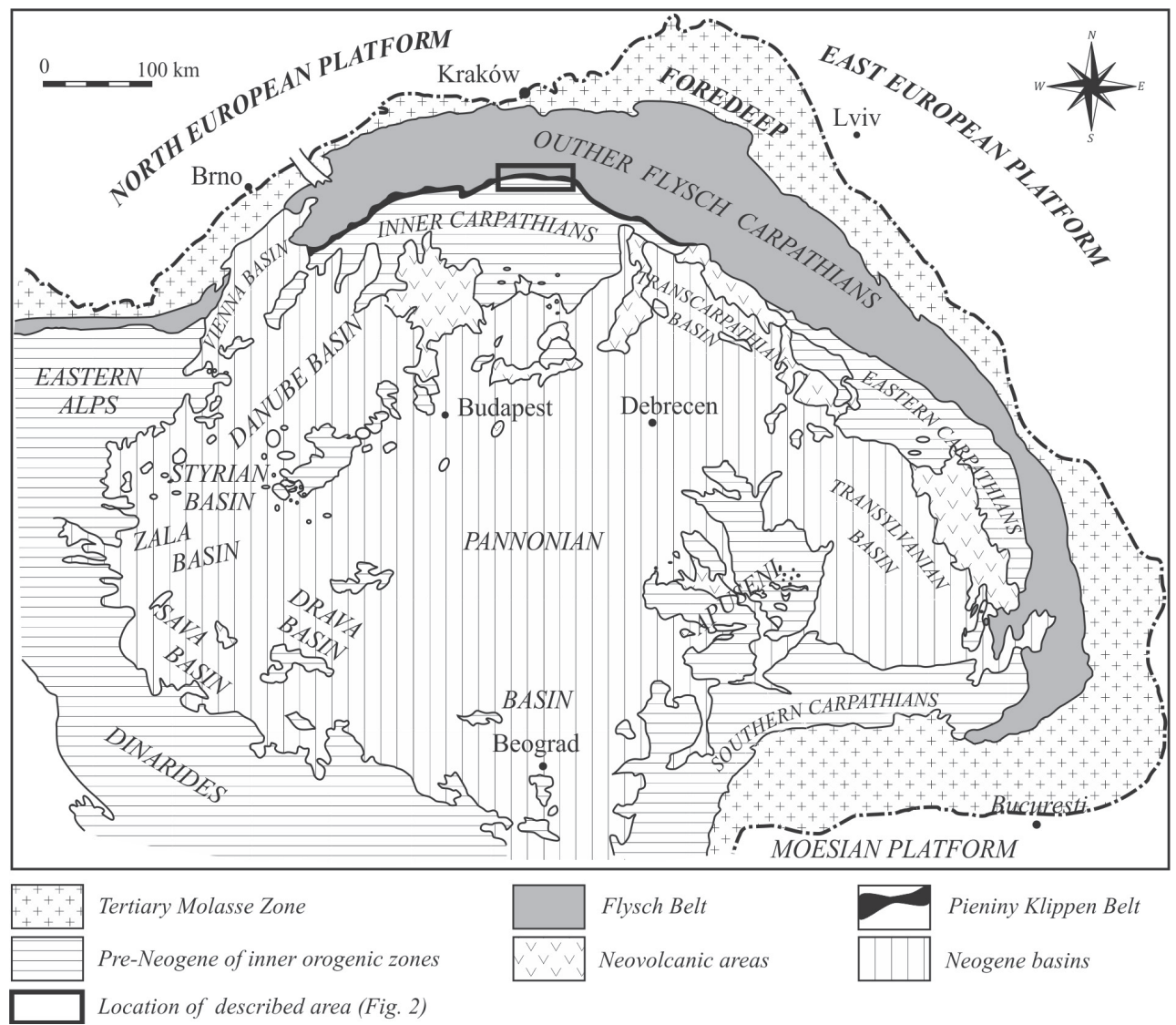

Fig. 1. Geological map of the Carpathians and adjacent areas with the location of the investigated areas (Fig. 2) (from Kováč et al. 1998, Golonka et al. 2011, modified)

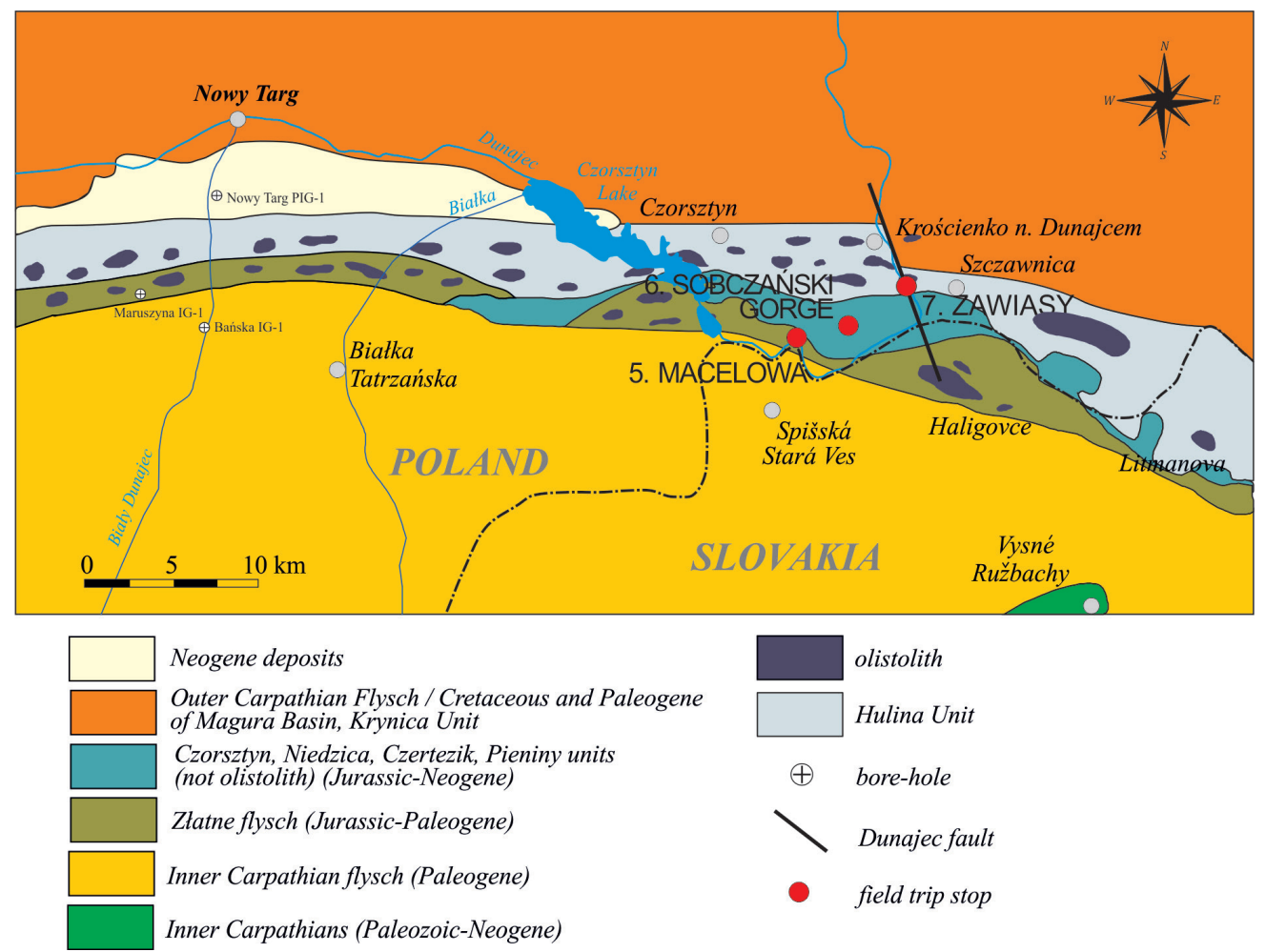

Fig. 2. Sketch map of the Pieniny Klippen Belt in Poland with the location of stop points (from Golonka et al. 2015, 2018, modified) 
The Klippen Belt is obliquely cut by NE-SW trending strike-slip faults. Their strike-slip kinematics is indicated by the presence of flower structures on the contact zone of the Magura Unit and the Klippen Belt, and by the asymmetry of the Central Carpathian Paleogene Basin (Golonka et al. 2005, Wierzbowski et al. 2006).

The tectonic character of the Polish section of the PKB is mixed. Both strike-slip and thrust components occur there (e.g. Książkiewicz 1977, Golonka \& Rączkowski 1984a, 1984b, Birkenmajer 1986, Ratschbacher et al. 1993, Jurewicz 1994, 1997, Nemčok \& Nemčok 1994). In general, the subvertically arranged Jurassic-Lower Cretaceous basinal facies rocks display a diapir-like nature genetically related to major displacements along the strike-slip zone between the Central Carpathian and North European plates. The PKB tectonic components of different age and characteristics, including strike-slipbounded tectonic blocks, thrust units, toe-thrusts and olistostromes mixed together, result in the present-day mélange characteristics of the PKB, where individual tectonic units are difficult to distinguish (Golonka et al. 2005, Wierzbowski et al. 2006).

The sedimentary rocks of the PKB were deposited in the paleogeographic realm known as the Alpine Tethys and divided into two basins separated by the Czorsztyn Ridge (Birkenmajer 1977, 1986, Golonka \& Krobicki 2004, Golonka et al. 2015, 2017). The formation of the Czorsztyn Ridge took place during the spreading phase in Bajocian times. Golonka \& Krobicki (2004) postulated the name of the Złatne Basin for the southeastern basin within the Alpine Tethys. According to Golonka et al. (2017), the Jurassic-Lower Cretaceous rocks deposited on the south-eastern slopes of the Czorsztyn Ridge represent the Czorsztyn, Niedzica, Czertezik, Branisko and Pieniny klippen successions (sensu Birkenmajer 1977, 1986, with modification by Wierzbowski et al. 2006). They constitute the so-called Pieniny Subbasin, which includes slope facies as well as rocks deposited on the Czorsztyn Ridge. The position of rocks deposited within the south-eastern part of the Alpine Tethys is more problematic, because of the multiplication of Slovak successions, such as Klape, Kostelec, Manín, Fodorka, Orava, Streženice, Drietoma/Bošáca, Nižná, Stupné, Chotúč, Hoština, Dúbravka, Michalova Hora (Golonka et al. 2017). The Magura Basin represented the northwestern part of the Alpine Tethys (Fig. 3).

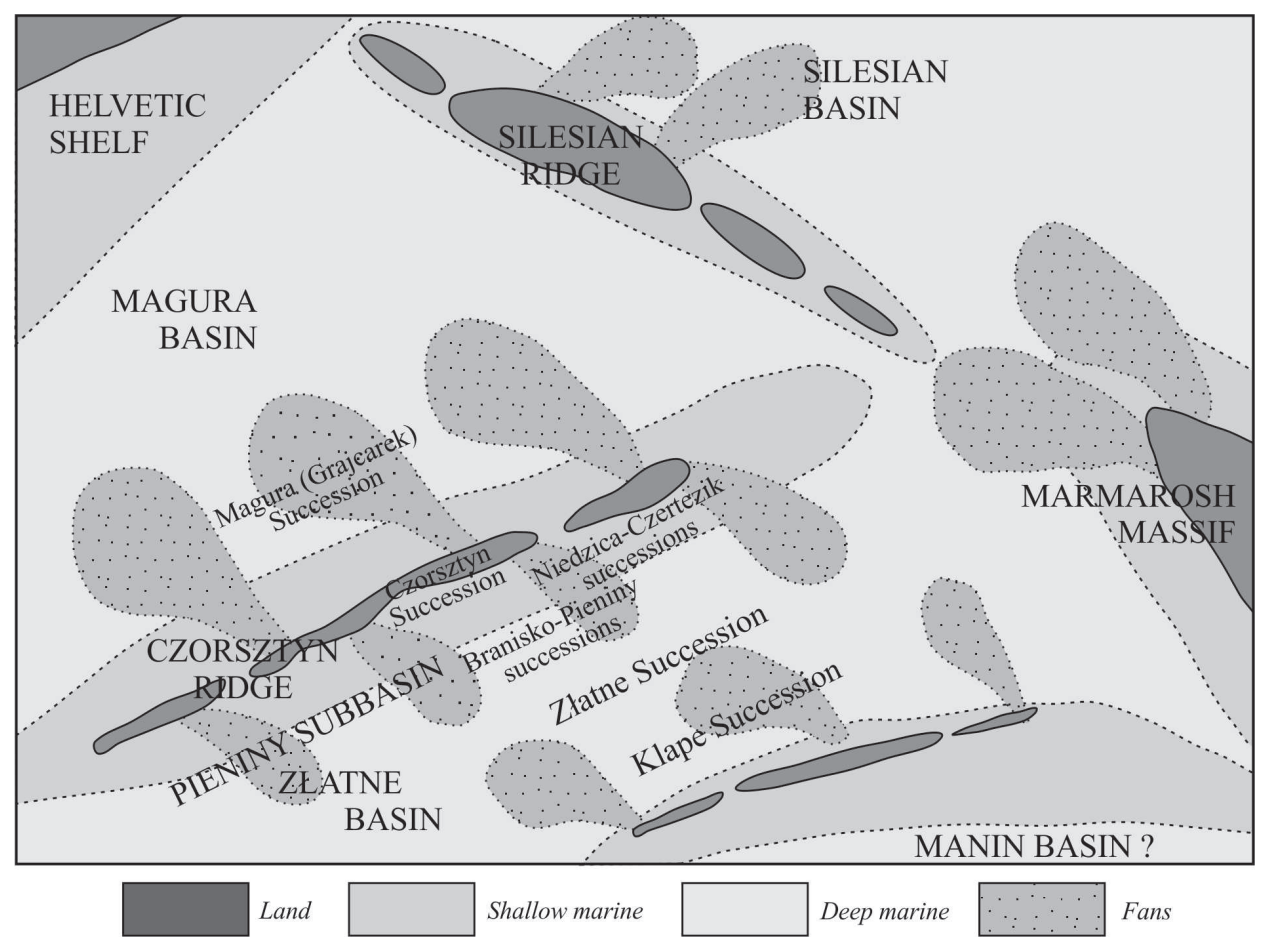

Fig. 3. Paleoenvironment and paleolithofacies with main paleogeographic element of the West Carpathians and adjacent areas during the Albian (from Golonka et al. 2017, modified). Plate position $112 \mathrm{Ma}$ 
The Jurassic-Lower Cretaceous rocks of the PKB are represented by several successions of mainly deep and shallower-water limestones. The Pieniny and Branisko (Kysuca) successions have been located within the deeper slope of the Pieniny Subbasin. The cherty limestones (Maiolica-type) of the Pieniny Limestone Formation constitute the most important facies within these successions (Fig. 4). They compose the main part of the Pieniny Mountains. Transitional sequences between the deeper slope and ridge units are known as the Niedzica and Czertezik successions (Pruské and Podbiel successions in Slovakia), located to the southeast of the Czorsztyn Ridge. Shallower pelagic facies were deposited on this ridge. The Pieniny Limestone Formation rocks were also deposited within the Magura Basin. Generally, the Pieniny Subbasin and Czorsztyn Ridge sedimentary history was tripartite (i-iii). It started with the sedimentation of (i) oxygen-reduced dark/black terrigenous deposits of Early to early Middle Jurassic age of the Gresten-type and Fleckenkalk/Fleckenmergel facies of Skrzypny Shale, Krempach Marl, Harcyground Shale and Podzamcze Limestone formations (Fig.4).

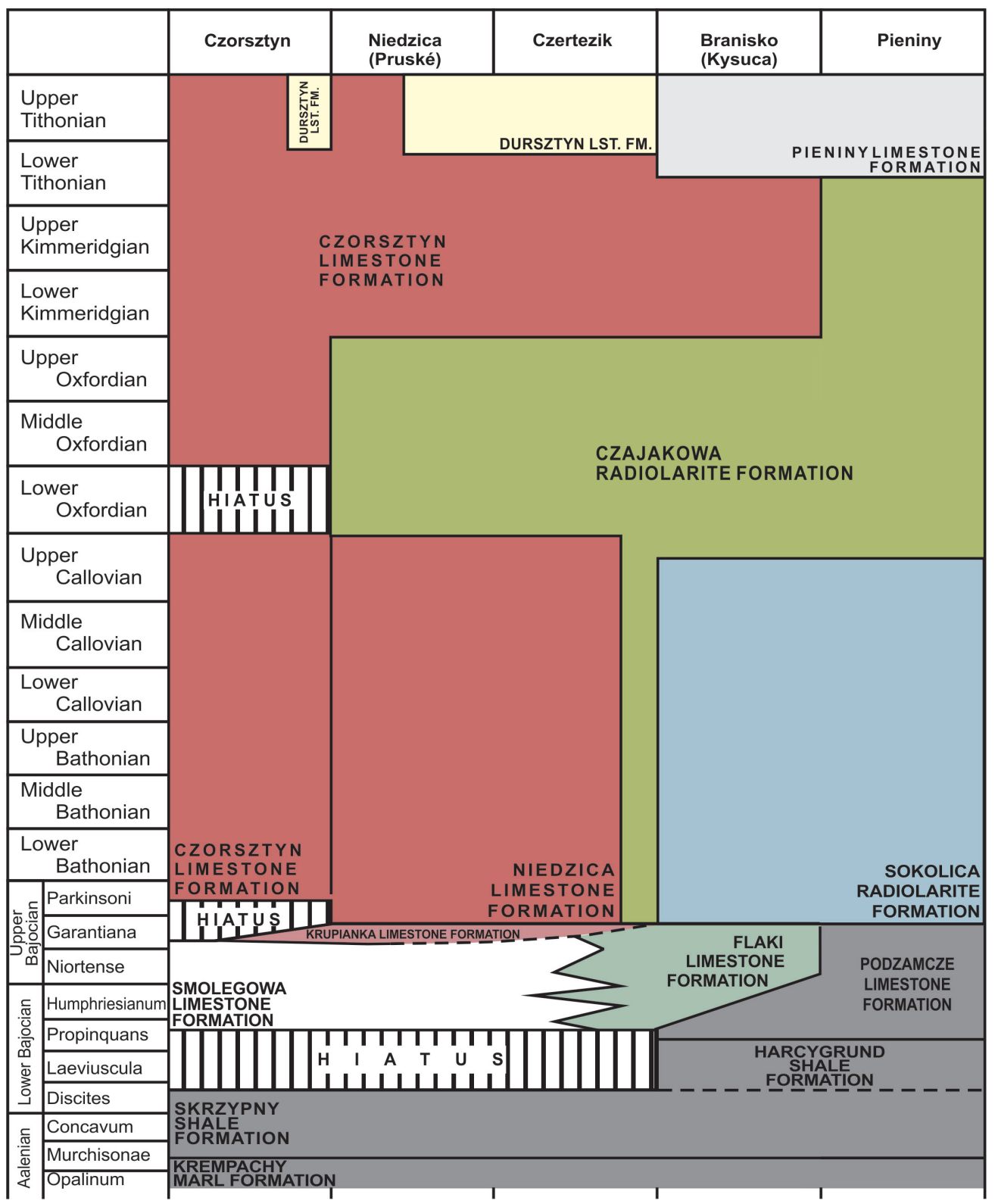

Fig. 4. Stratigraphic table of the Jurassic rocks of the Czorsztyn, Niedzica (Pruské), Czertezik, Branisko (Kysuca) and Pieniny successions of the Klippen Belt in Poland and bordering part of Slovakia (from Wierzbowski et al. 2006, simplified) 
Its continuation resulted in (ii) Middle Jurassic-earliest Cretaceous crinoidal (Smolegowa and Flaki Limestone formations), nodular limestone of the ammonitico rosso-type belonging to Czorsztyn and Niedzica Limestone formations or cherty of the Maiolica (Biancone)-type limestones of the Pieniny Limestone Formation and radiolarites of Czajakowa and Sokolica Radiolarite formations that were eventually replaced by (iii) Late Cretaceous pelagic marls of the Jaworki Formation (Scaglia Rossa $=$ Couches Rouge $=$ Capas Rojas) facies and/or flysch/flyschoidal series (Fig. 5) (i.a. Birkenmajer 1986, 1988, Miš́k 1994, Aubrecht et al. 1997, Bąk 2000, Golonka \& Krobicki 2004).

The Albian-Upper Cretaceous rocks of the Alpine Tethys are represented by flysch deposits and pelagic marls (Fig. 5). The flysch sedimentation continued through the Paleogene and even Neogene times. The flysch sequences contain numerous exotics. Large exotic blocks constitute olistoliths (Golonka et al. 2014, 2017). The exotics from the Złatne Basin represent mainly Central Carpathian material, while the exotics from the Magura Basin contain a lot of material derived from the Pieniny Subbasin and Czorsztyn Ridge successions. The rocks of the marginal part of the Magura Basin incorporated into the Pieniny Klippen Belt structure are known as the Hulina (also referred as Grajcarek or Šariš) Unit (see Sikora 1962, Golonka \& Sikora 1981, Birkenmajer1986, 1988, Golonka \& Krobicki 2004, Pieńkowski et al. 2008, Plašienka 2012, Oszczypko et al. 2015, Birkenmajer \& Gedl 2017). This unit is often thrust over the Krynica Sub-Unit of the Magura Nappe.

During Late Cretaceous-Paleocene times, an accretionary prism formed in front of the advancing Alcapa (Central Carpathians) terrane which had overridden the Czorsztyn Ridge. The destruction of the Czorsztyn Ridge supplied huge amounts of coarse-clastic material, including olistoliths, into the Magura Basin (Golonka et al. 2015, 2017). These olistoliths have recently been located within the flysch deposits of the Hulina Unit. The Alcapa terrane continued its northward movement during Paleogene-Early Miocene times (Golonka et al. 2006a).

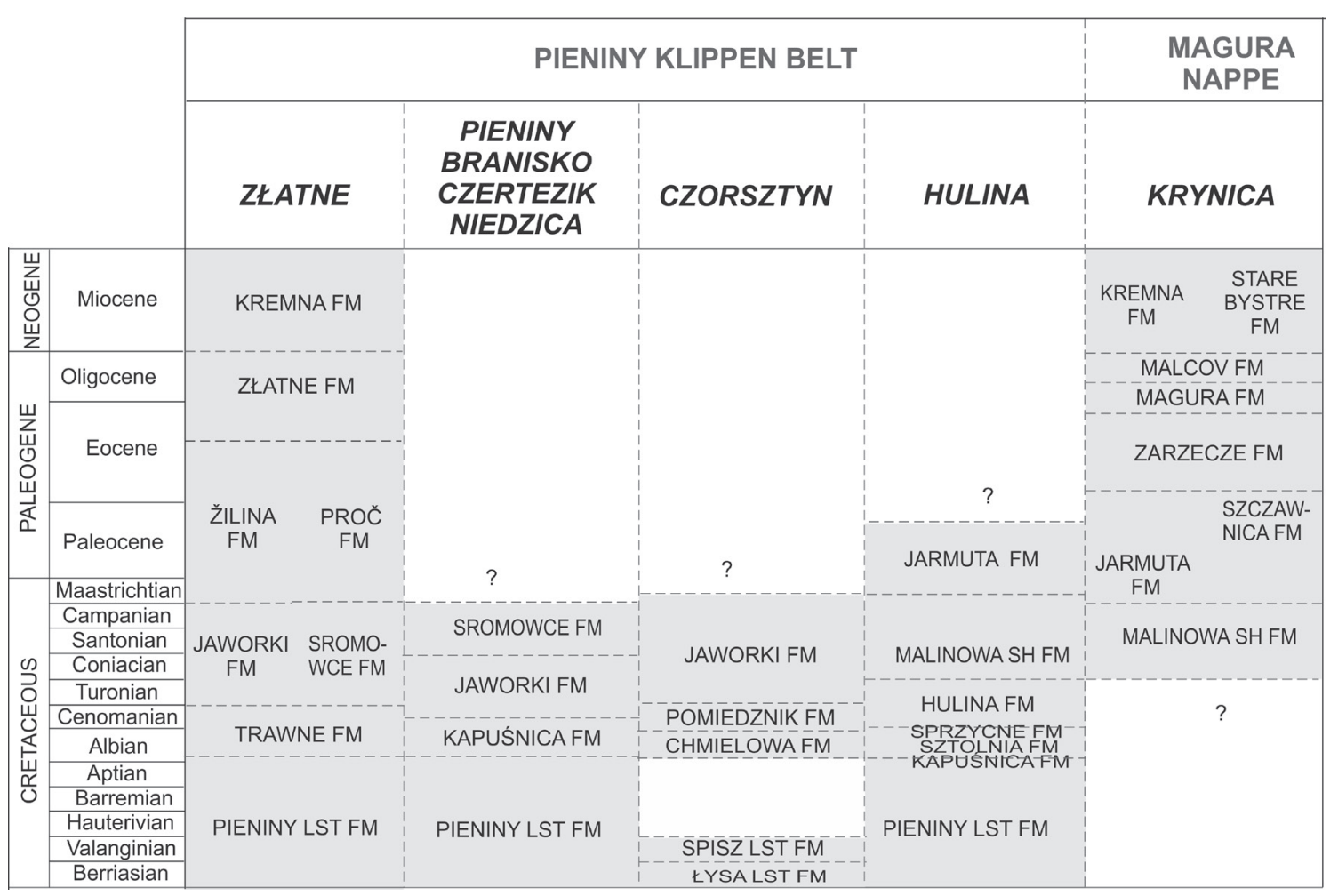

Fig. 5. General stratigraphic table of the Cretaceous rocks of the Pieniny Klippen Belt and adjacent part of the Outer Carpathian Magura Nappe in Poland and bordering part of Slovakia (compiled from Andrusov 1965, Sikora 1971, Birkenmajer 1977, Golonka \& Sikora 1981, Potfaj 1997, Golonka et al. 2006b, 2015, Oszczypko \& Oszczypko-Clowes 2010, Golonka \& Waśkowska 2014, Oszczypko et al. 2015) 
This movement led to further development of the accretionary prism and the formation of flysch nappes. The Inner Carpathian plates and uprooted Outer Carpathian flysch units were thrust over the North European Platform. The rotation of the Alcapa plate (Márton et al. 1999, 2004, 2013, Csontos \& Vörös 2004, Golonka 2005) caused the strikeslip motions along the Central Carpathian-North European Platform boundary. This led to the deformation of the previously created nappes in the Pieniny Klippen Belt. A flower structure developed forming two parallel faults that delineate the southern and northern limit of the PKB. Similar phenomena were observed in the eastern part of the PKB in Slovakia where, according to Hrušecký et al. (2006), the boundary zone was reactivated several times during the Paleogene-Neogene as transpressional and/or transtensional (see also Ratschbacher et al. 1993, Nemčok \& Nemčok 1994), forming the vertical flower structure of the PKB. According to Marko et al. (2017), the western segment of the PKB displays faults formed in a strike-slip regime during the early stages of its Neo-Alpine tectonic evolution.

The last important event in the PKB was Middle Miocene (Sarmatian) volcanism, represented by calc-alkaline andesite dykes and sills which cut the mainly Paleogene flysch rocks of the Outer Carpathians (Magura Nappe). They are linked with the so-called Pieniny Andesitic Line (PAL) (Birkenmajer 1986, 1988, Birkenmajer \& Pécskay 1999, Jurewicz \& Nejbert 2005, Nejbert et al. 2012, Anczkiewicz \& Anczkiewicz 2016).

The complex characteristics of the PKB have caused a multitude of still unsolved problems, questions and controversies (see Plašienka 2012, Golonka et al. 2017, Jurewicz 2018). The authors of this guide share a general view on the geology of the $\mathrm{PKB}$, while expressing differences concerning the nomenclature of the tectonic units, among the others. For example, Golonka et al. (2017) stated "we do not see any advantages in producing new names such as Šariš. This causes only more confusion for the reader not familiar with the peculiarities of correlation across the state borders" and "we should avoid the situation from the past, when the same formations, basins or tectonic units obtained different names in different countries". The authors of this paper hope that all possible questions and unresolved problems can be discussed during the field session whose successive stops are presented below.

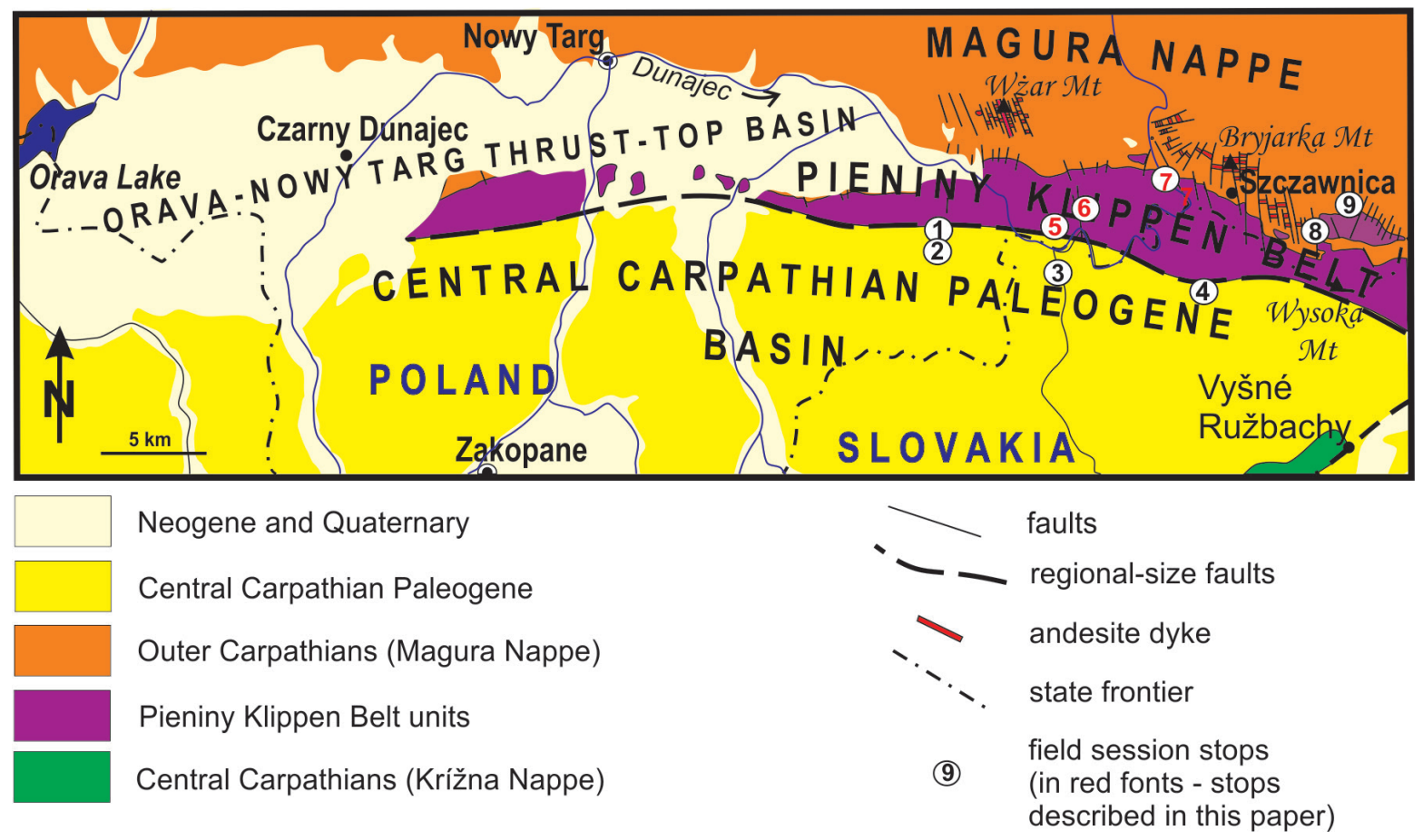

Fig. 6. Approximate location of field session stops on generalized geological map showing tectonic setting of the Pieniny Klippen Belt in Poland (based on Birkenmajer 1979 and Jurewicz 2005) 


\section{STOP 5}

Macelowa. Sromowce Wyżne (Kąty) village, $1 \mathrm{~km}$ east of the Kąty Dunajec rafting harbor $49^{\circ} 24^{\prime} 27.8^{\prime \prime N} ; 20^{\circ} 22^{\prime} 35.9^{\prime \prime} \mathrm{E}$

Overturned position of the deformed, rotated counterclockwise, Pieniny Succession rock in the southern marginal zone of the Pieniny Klippen Belt

Strongly folded Jurassic-Cretaceous strata are visible along the road from Sromowce Wyżne to
Sromowce Niżne, close to the Dunajec River, on the southern slope of Mt. Macelowa (Figs. 2, 6, 7), where the Pieniny Succession rocks lie in an overturned position. The oldest Oxfordian radiolarites occupy the topmost part of Mt. Macelowa (on its northern slope), gray cherty limestones of the Maiolica facies (Pieniny Limestone Formation) occupy the transitional position and in the lowest (topographically) position are the Late Cretaceous Globotruncana-bearing marls of the Scaglia Rossa-type (Birkenmajer 1977, Bąk 1998, 2000).
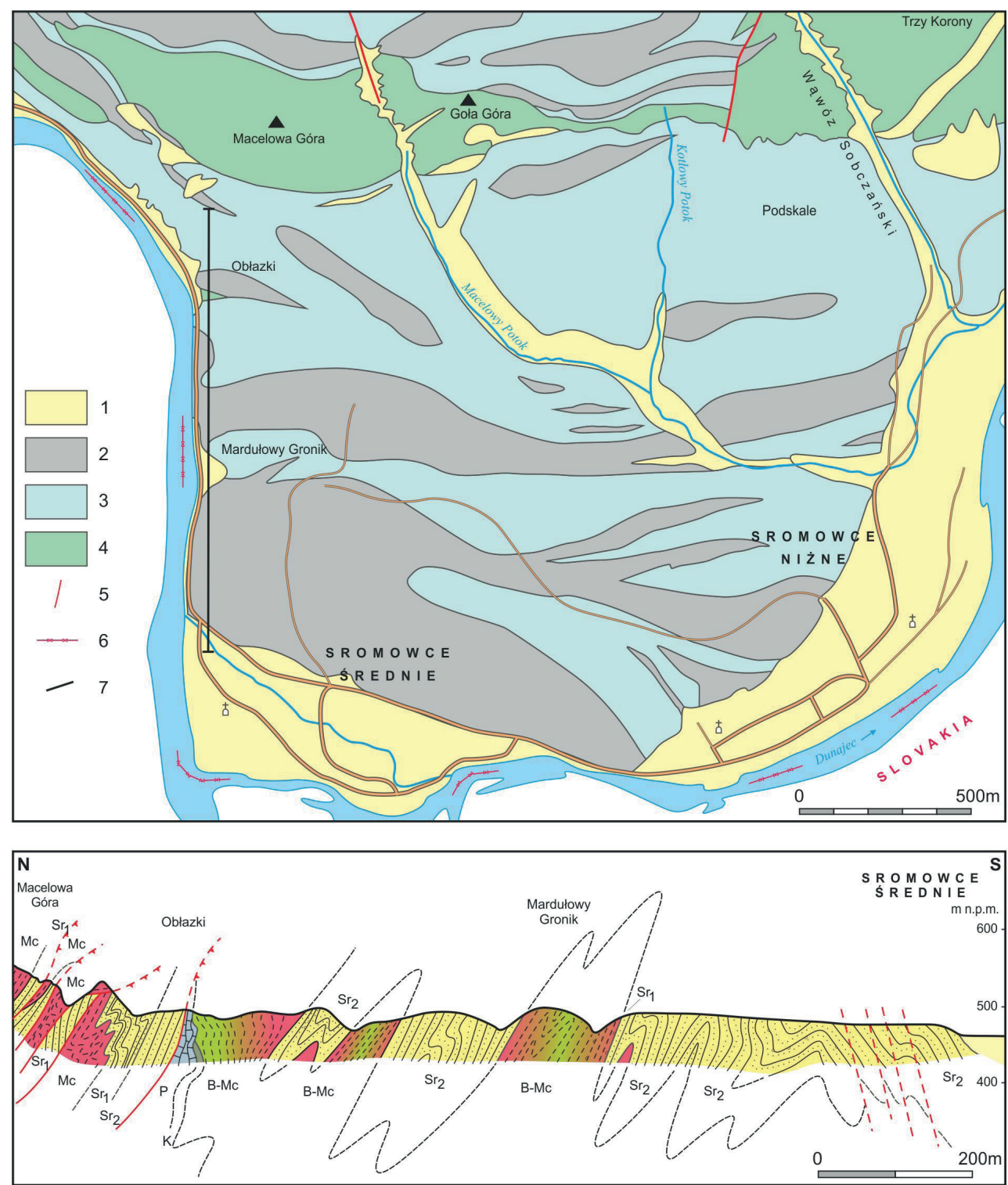

Fig. 7. Geological map of the vicinity of Sromowce (after Horwitz 1963, Birkenmajer \& Jednorowska 1984, simplified) and geological cross-section: 1 - Quaternary; 2 - Sromowce Formation; 3 - Jaworki Formation, partly Kapuśnica Formation; 4 - Pieniny Limestone Formation, partly also Czajakowa Radiolarite Formation; 5 - faults; 6 - state border; 7 - geological cross-section (below); P - Pieniny Limestone Formation (grey cherty limestones); $K$ - Kapuśnica Formation (green spotty marls); B-Mc - Jaworki Formation (Brynczkowa, Skalski and Macelowa Marl members - green, variegated and red marls respectively); Sr - Sromowce Formation (Sr $r_{1}$ Osice Siltstone Member; $\mathrm{Sr}_{2}$ - flysch) 


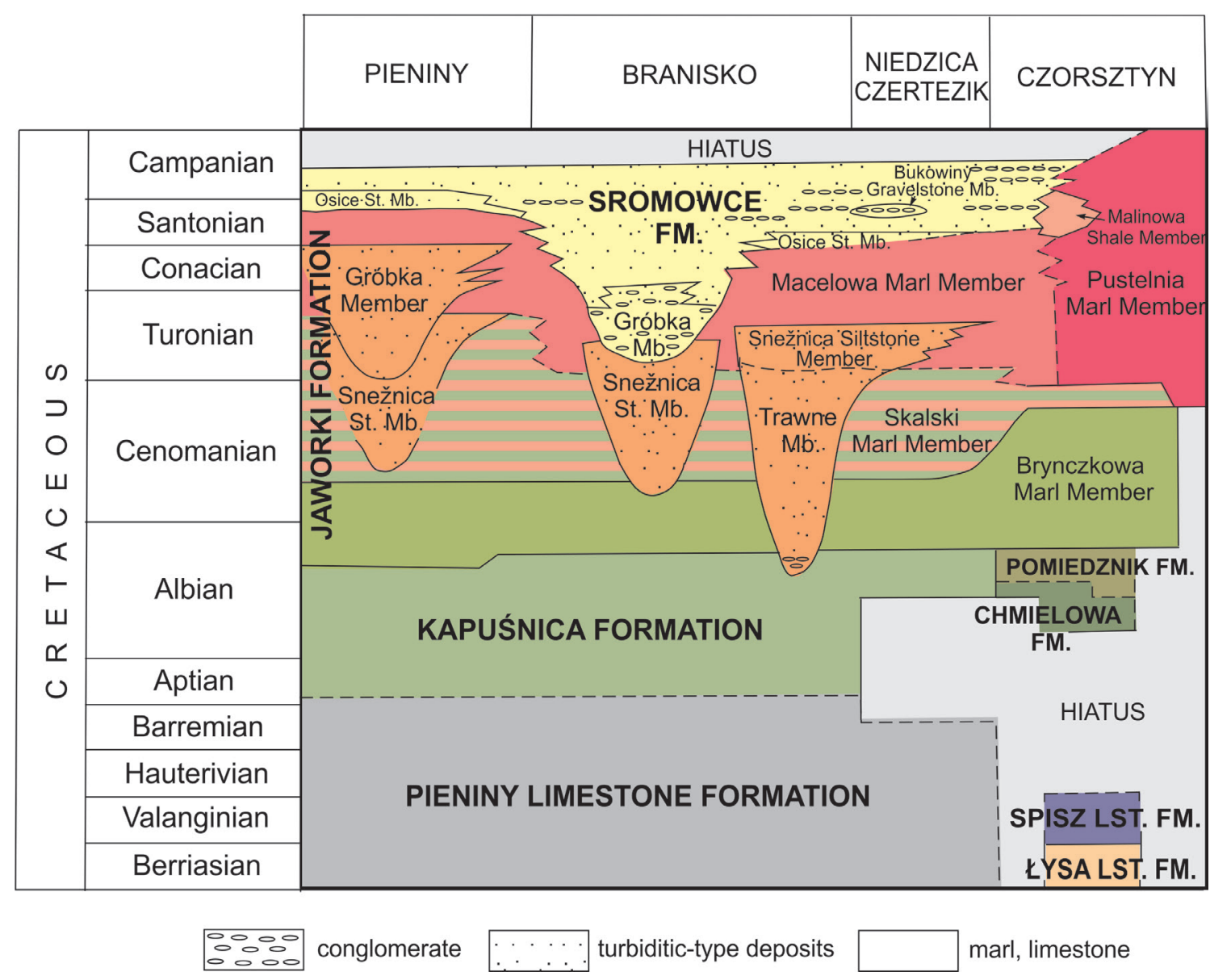

Fig. 8. Detailed stratigraphic table of the Cretaceous rocks of the Czorsztyn, Niedzica (Pruské), Czertezik, Branisko (Kysuca) and Pieniny successions in the Pieniny Klippen Belt in Poland (from Birkenmajer \& Jednorowska 1987, simplified)

Previously, this unit had been named the Jaworki Marl Formation (Birkenmajer 1977, 1979), but after the discovery of several siliciclastic (flysch-flyschoid/turbidite wedges in origin) intercalations within it (e.g. Snežnica Siltstone Member, Gróbka Member, Osice Siltstone Member; see Birkenmajer \& Jednorowska 1987). Birkenmajer (1987) revised its name and replaced it with the Jaworki Formation. Figure 8 depict the Birkenmajer \& Jednorowska (1987) ideas about the Cretaceous lithostratigraphy of the Pieniny Mountains. It is certainly controversial; note that the Gróbka Member was assigned to two different formations and also that the position of the Trawne Member is quite speculative, compare Figure 5 (Sikora 1971, Golonka \& Sikora 1981). Red marls and marly limestones of pelagic deposits with grayish intercalations of calcareous sandstones and siltstones of distal turbiditic origin predominate in this outcrop (Fig. 9). This is the youngest part of the multicolored (green-variegated-red) globotruncanid marls of the so-called Macelowa Marl Member of the Jaworki Formation, with good foraminiferal Upper Cretaceous biozonation (Dicarinella concavata - D. asymmetrica foraminiferal zones of the Upper Coniacian-Santonian) (Bąk 1998, 2000). These deposits originated during the final episode of the evolution of the $\mathrm{PKB}$, when the unification of sedimentary facies took place within all the successions. Widespread in the Late Cretaceous Tethyan Ocean, the Scaglia Rossa-type facies $(=$ Couches Rouge $=$ Capas Rojas) represented by the Jaworki Formation indicate wide connections between several branches of this ocean. The paleomagnetic investigation indicated the counterclockwise rotation of rocks collected in this location (Márton et al. 2013). This rotation caused the strike-slip motions along the Central Carpathian-North European Platform boundary. 

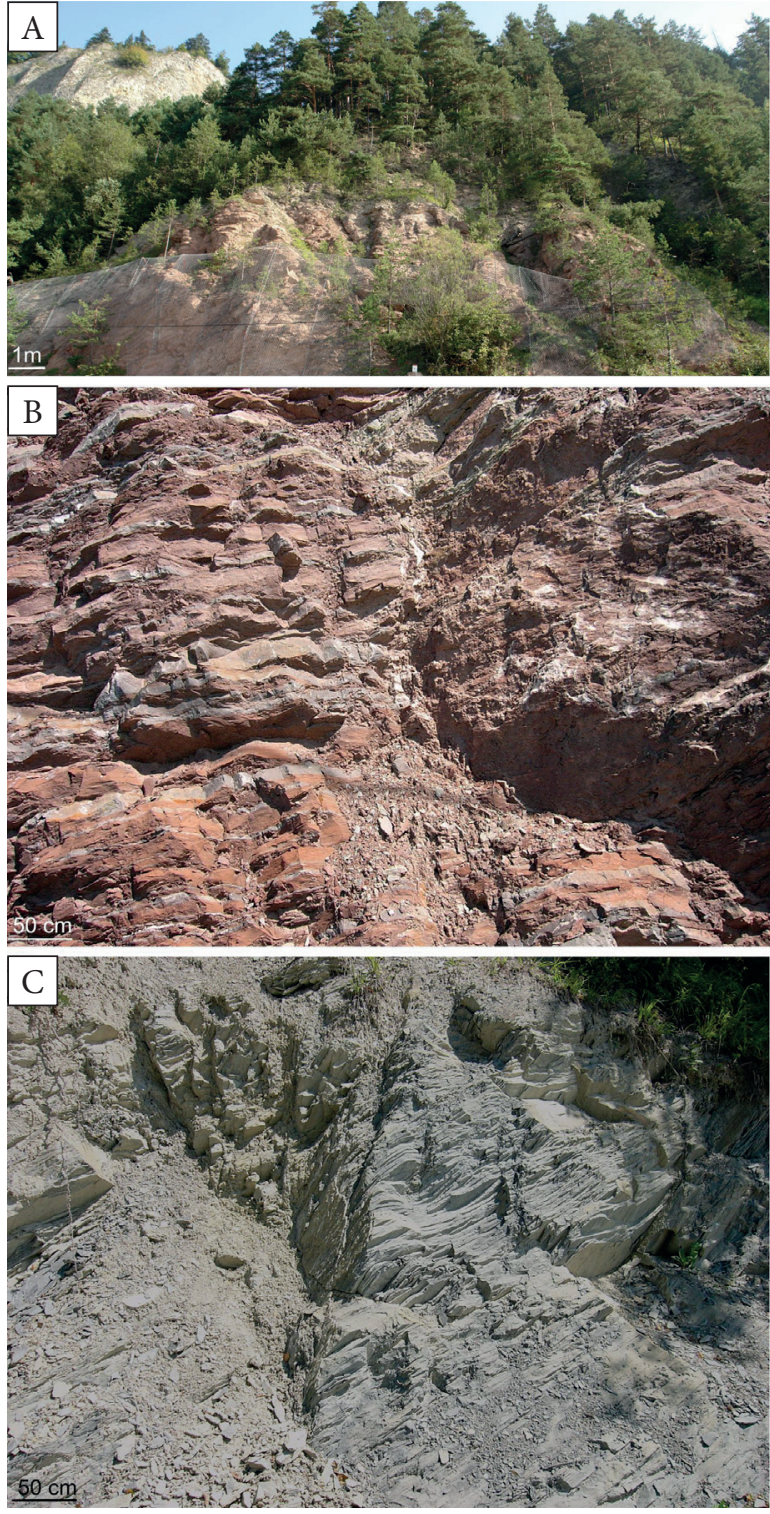

Fig. 9. General view of Mt. Macelowa from the Dunajec River (raft) (A). Macelowa Member (Scaglia Rossa-type red Globotruncana marls) of the Jaworki Formation in the lower part of Mt. Macelowa (B). Upper Cretaceous grey mudstones of the Snieznica Siltstone Member of the Jaworki Formation in the lower part of Mt. Macelowa (C)

\section{STOP 6}

Sobczański Gorge. Pieniny Mountains, 1 km north of the parking lot in Sromowce Wyżne village $49^{\circ} 24^{\prime} 48.5^{\prime \prime} \mathrm{N} ; 20^{\circ} 24^{\prime} 54.6^{\prime \prime} \mathrm{E}$

Diapiric uplift of the Pieniny rocks in a transpressional strike-slip regime

After passing Mt Macelowa, the Dunajec River crosses the major vertical strike-slip fault separating the PKB from the rolling hills of the Central
Carpathians. These hills are composed of turbiditic sandstones, mudstones and shales deposited within the Spiš depression of the Central Carpathian Paleogene. This basin includes the Podhale, Liptov, Orava and Spiš depressions. Its sedimentary fill includes Paleogene deposits underlain by mostly calcareous Mesozoic rocks. After a retreat of the Late Cretaceous sea, the subsequent transgression took place in the Middle Eocene and, in its initial phase resulted in the formation of conglomerates and limestones. These deposits form the base member of the Central Carpathian Paleogene. Subsequently, typical flysch deposits were formed. The greatest thickness of these deposits ca. $3000 \mathrm{~m}$, was encountered in the Chochołów PIG-1 borehole (Golonka et al. 2005, Golonka \& Krobicki 2007).

The Szaflary Beds occurring in the northern part of the basin, bordering the PKB are generally considered as one of the oldest flysch members or units (Chowaniec \& Kępińska 2003, Golonka et al. 2005).

The younger members are represented by the shaly flysch rocks of the Zakopane Beds. The Slovak equivalent of the Zakopane Beds is the Huty Formation. The Chochołów or Zuberec Formation, overlying the Zakopane Beds, represents typical flysch facies. The youngest Central Carpathian Paleogene flysch rocks belong to Ostrysz or Biely Potok Formation (Golonka et al. 2005, Golonka \& Krobicki 2007).

At Sromowce Niżne village, the Dunajec River again enters the PKB. There, the magnificent limestone walls of Trzy Korony Mountain (982 m a.s.l.), the highest mountain group of the Pieniny Mts, marks the beginning of the most beautiful part of the Pieniny Mountains - the Dunajec River Gorge (Birkenmajer et al. 2001, Golonka \& Krobicki 2007).

The origin of this gorge is related to neotectonic movements during the Neogene. Following the Serravallian formation of the Outer Carpathian fold-and-thrust belt, the area at the Central and Outer Carpathian boundary was covered by at least $600-900 \mathrm{~m}$ of Neogene sand, silt and clay (Chrustek \& Golonka 2005, Golon$k a$ et al. 2005). The Dunajec River valley reached the mature stage during the latest Miocene-Pliocene time. This is indicated by the numerous meandering bends of the river. The vertical uplift of the Pieniny Mountains followed the meandering stage of the Dunajec (Birkenmajer 2006). 

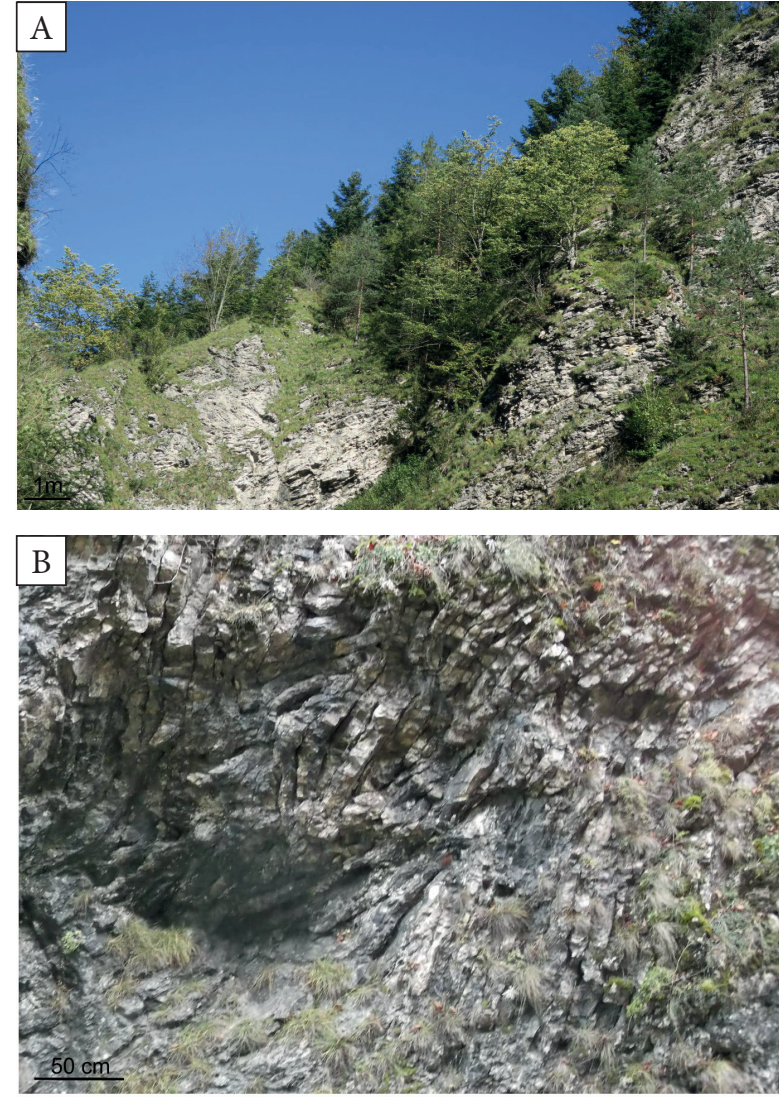

Fig. 10. Sobczański Gorge. The walls of the gorge expose the Pieniny Limestone Formation (A). Strongly deformed rocks of the Pieniny Limestone Formation in the Sobczański Gorge (B)

Faulting and uplifting played a tremendous role during the Neogene tectonic evolution of the PKB in Poland. At least some of the faults were still active during the Quaternary (Baumgart-Kotarba 1996, 2001, Zuchiewicz et al. 2002). The seismic data of local earthquakes recorded in the Podhale-PKB region supplied the evidence that tectonic faults in this area are still seismically active (Guterch et al. 2005, Białoń et al. 2015). Recent vertical movements in the area are estimated at up to + $0.5 \mathrm{~mm}$ per year (Vanko 1988, Vass 1998). During the fault-related uplift of the Pieniny Mountains, the Dunajec River cut into the competent Jurassic-Early Cretaceous cherty limestones that formed the magnificent cliffs of the gorge (Golonka \& Krobicki 2007).

The trip follows the tourist trail from Sromowce Niżne to the Trzy Korony Mountain. The village of Sromowce Niżne (Fig. 7) is located on the less competent rocks of the Kapuśnica, Jaworki and Sromowce formations (Figs. 5, 8), while the Trzy Korony massif is built of the vertically or subvertically dipping more competent rocks of the Pieniny Limestone Formation, which makes a distinctive difference in morphology. The Sobczański Gorge cuts into the rocks of the Pieniny Limestone Formation, allowing the observation of tectonic deformation structures in the cherty limestones (Fig. 10). These structures originated during a diapiric uplift of the Pieniny Succession rocks in a transpressional strike-slip regime during the Neogene.

\section{STOP 7}

Zawiasy. Pieniny Mountains, $1 \mathrm{~km}$ south of the market square in the town of Krościenko $49^{\circ} 25^{\prime} 33.3^{\prime \prime} \mathrm{N}$; $20^{\circ} 26^{\prime} 27.4^{\prime \prime} \mathrm{E}$

Northern marginal zone (Hulina Unit) of the Pieniny Klippen Belt; major dextral strike-slip of the Dunajec Fault

All of the rocks exposed in the Zawiasy Klippe (Figs. $2,6,11-13)$ represent the fragments of the Magura Basin fill defined by Golonka \& Sikora (1981) as the Hulina (also referred to as Grajcarek or Šariš) Unit, that were incorporated into the PKB. They were deposited between the Czorsztyn Ridge and a deeper part of the Magura Basin during the Middle Jurassic through to the Paleocene (Golonka et al. 2006b). The bulk of the Klippe is formed of the Biancone/Maiolica-type cherty limestones (Pieniny Limestone Formation) - of latest Jurassic-Early Cretaceous age. The Hedbergella microfacies with Hedbergella sp., Praeglobotruncana sp. and Thalmaninella ticenensis (Gandolfi) was found in the uppermost part of the limestones (Golonka \& Sikora 1981). It suggests the Albian age of the youngest part of the Pieniny Limestone Formation in the slope succession of the Magura Basin. The rocks of the Pieniny Limestone Formation are covered by Upper Cretaceous marls of the Kapuśnica and Jaworki formations. All of these rocks form part of a large olistolith deposited within the flysch of the Jarmuta Formation (Fig. 13D).

The boundary between the Krynica facies zone of the Magura Nappe and the PKB in Poland was distinguished mainly on tectonic premises (Golonka \& Rączkowski 1981a, 1981b, Kulka et al. 1985, Birkenmajer \& Oszczypko 1989, Chrustek et al. 2005, Oszczypko et al. 2006). Deposits older than the Late Cretaceous do not crop out in the Krynica Zone (Oszczypko \& Oszczypko-Clowes 2010). 


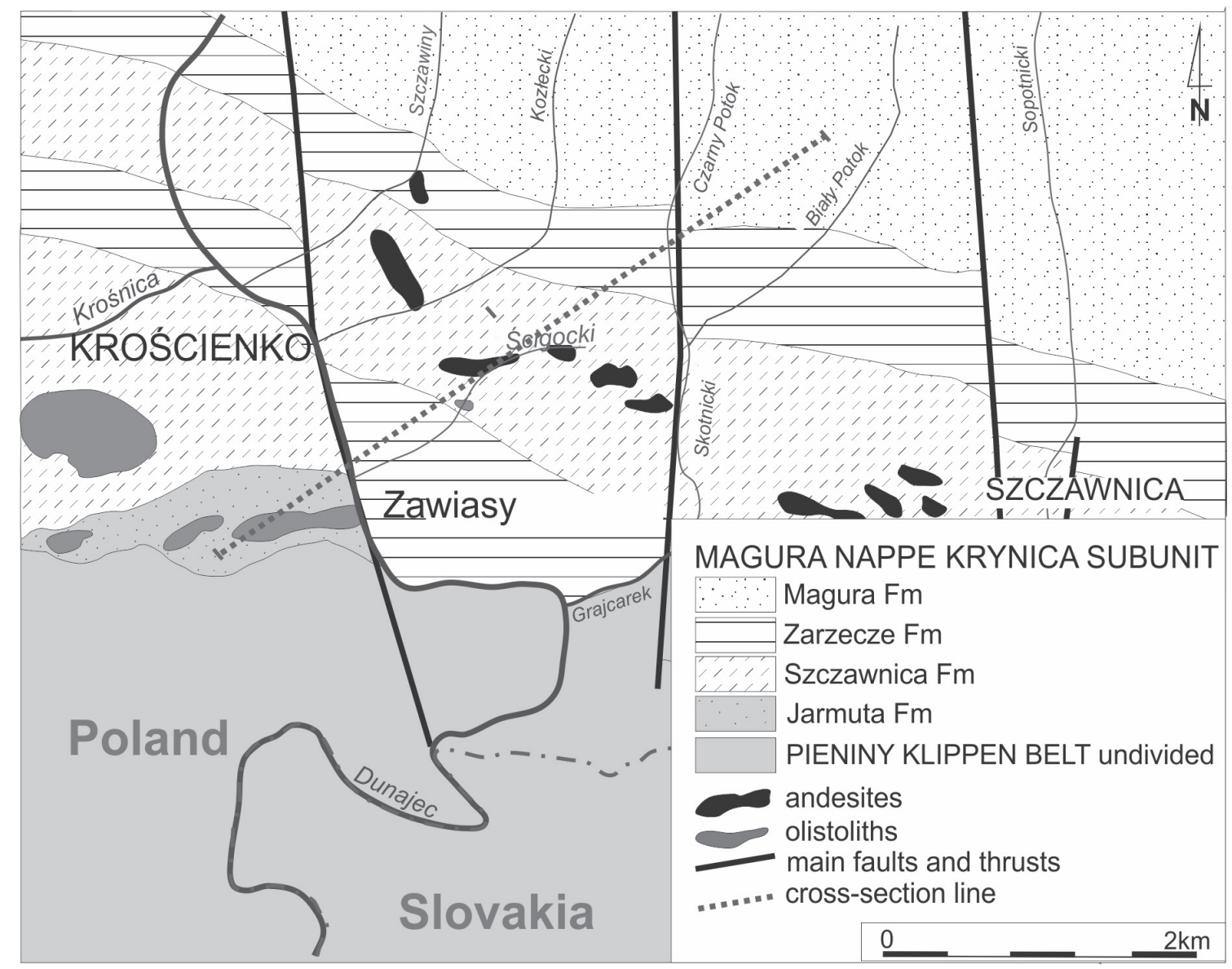

Fig. 11. Geological map of Zawiasy area (from Golonka \& Waśkowska 2014, modified)

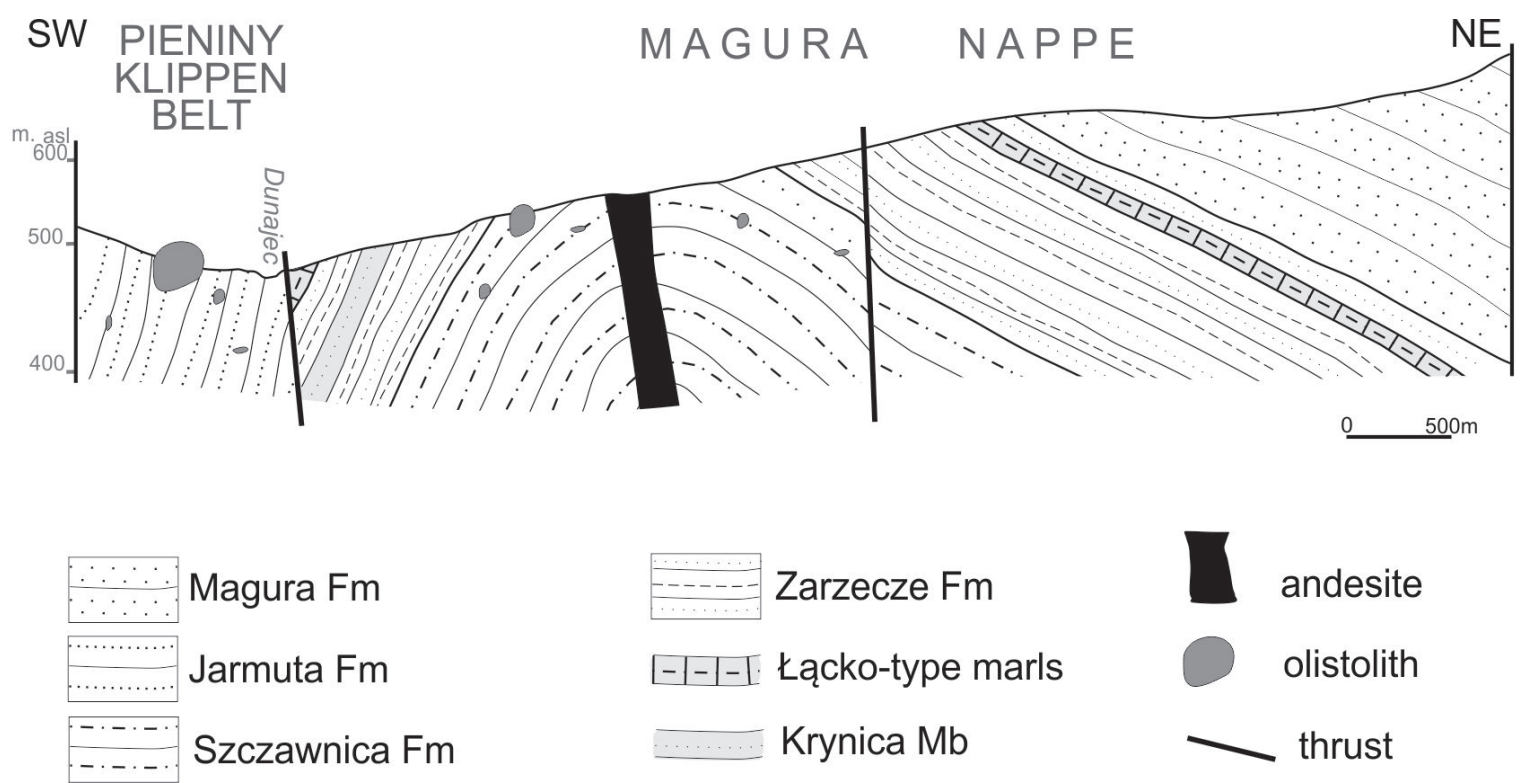

Fig. 12. Cross-section between the Pieniny Mts in the Zawiasy area and the slopes of Beskid Sadecki (from Golonka \& Waśkowska 2014, modified) 

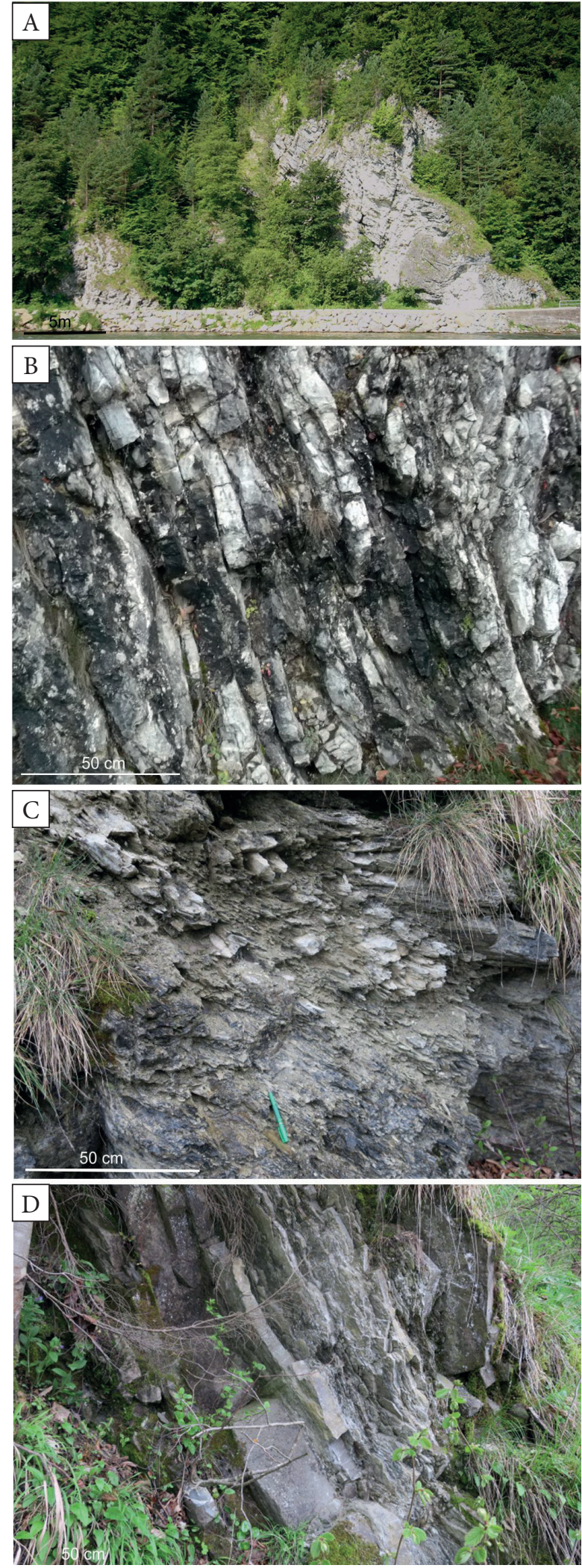

Fig. 13. General view of the Zawiasy Klippe (A). Deformed rocks of the Pieniny Limestone Formation in the Zawiasy olistolith (B). Deformed rocks of the Jaworki Formation in the Zawiasy olistolith (C). Flysch of the Jarmuta Formation in the Zawiasy Klippe (D)
The PKB also includes Upper Cretaceous-Oligocene rocks deposited within the Magura Basin. The uppermost Cretaceous-Paleocene deposits within the Magura Basin are widespread both in the Magura Nappe, where they are known as the Szczawnica Formation, whereas in the PKB they are referred to as the Jarmuta Formation. The facies changes between these formations are often difficult to distinguish because of tectonic disturbance. Both formations include coarse-grained sandstones, conglomerates, and olistostromes with Jurassic and Cretaceous calcareous rocks. The amount of these deposits greatly increases in the Jarmuta Formation, indicating the more proximal character of the deposition. The Szczawnica and Jarmuta formations are quite closely related, representing proximal and distal facies of slope and rise turbidites.

A major strike-slip, right lateral fault is located along the Dunajec River stretch adjacent to the stop. The mountains on the left side of the Dunajec represent the Pieniny Mountains and, geologically, the Hulina Unit. The mountains on the right side of the Dunajec belong to the Beskid Sądecki range and are built of flysch rocks of the Krynica facies unit of the Magura Nappe (Figs. 11, 12). A small fragment of this unit is exposed on the left bank of the Dunajec, north of the main Zawiasy outcrop. It is represented by Eocene Lącko type marls of the Zarzecze Formation. The main tectonic boundary between the PKB and Magura Nappe runs from west to east along the slopes of the Pieniny Mountains, south of the town of Krościenko. This boundary follows a major dextral strike-slip Dunajec Fault (Golonka \& Waśkowska 2014).

This research has been financially supported by the National Centre for Research and Development (NCBiR) grant no. BG2/ShaleCarp/14, National Science Centre (NCN) grant 2016/23/B/ST10/01896 as well as the AGH University of Science and Technology in Kraków grant no. 11.11.140.005.

\section{REFERENCES}

Anczkiewicz A.A. \& Anczkiewicz R., 2016. U-Pb zircon geochronology and anomalous Sr-Nd-Hf isotope systematics of late orogenic andesites: Pieniny Klippen Belt, Western Carpathians, South Poland. Chemical Geology, 427, 1-16. 
Andrusov D., 1965. Geologie der tschechoslowakischen Karpaten. Band II. SAV, Academie Verlag, Bratislava, Berlin.

Aubrecht R., Mišík M. \& Sýkora M., 1997. Jurassic synrift sedimentation on the Czorsztyn Swell of the Pieniny Klippen Belt in Western Slovakia. [in:] Plašienka D. Hók J., Vozár J. \& Ellecko M. (eds.), Alpine evolution of the Western Carpathians and related areas, Dionýz Stur Publisher, Bratislava, 53-64.

Bąk K., 1998. Planktonic foraminiferal biostratigraphy, Upper Cretaceous red pelagic deposits, Pieniny Klippen Belt, Carpathians. Studia Geologica Polonica, 111, 7-92.

Bąk K., 2000. Biostratigraphy of deep-water agglutinated Foraminifera in Scaglia Rossa-type deposits of the Pieniny Klippen Belt, Carpathians, Poland. [in:] Hart M.B. Kaminski M.A. \& Smart C.W. (eds.), Proceedings of the Fifth International Workshop on Agglutinated Foraminifera: Plymouth, U.K., September 6-16, 1997, Grzybowski Foundation Special Publication, 7, Grzybowski Foundation, 15-41.

Baumgart-Kotarba M., 1996. On origin and age of the Orava Basin, West Carpathians. Studia Geomorphologica Carpatho-Balcanica, 30, 101-116.

Baumgart-Kotarba M., 2001. Continuous tectonic evolution of the Orava basin from Late Badenian to the present-day. Geologica Carpathica, 52, 103-110.

Białoń W., Zarzycka E. \& Lasocki S., 2015. Seismicity of Czorsztyn Lake Region: A Case of Reservoir Triggered Seismic Process. Acta Geophysica, 63, 4, 1080-1089.

Birkenmajer K., 1977. Jurassic and Cretaceous lithostratigraphic units of the Pieniny Klippen Belt, Carpathians, Poland. Studia Geologica Polonica, 45, 1-158.

Birkenmajer, K., 1979. Przewodnik geologiczny po pienińskim pasieskałkowym. Wydawnictwa Geologiczne, Warszawa.

Birkenmajer K., 1986. Stages of structural evolution of the Pieniny Klippen Belt, Carpathians. Studia Geologica Polonica, 88, 7-32.

Birkenmajer K., 1987. The Trawne Member (Upper Albian Upper Cenomanian) - a flysch development in the Branisko Nappe, Pieniny Klippen Belt, Carpathians. Studia Geologica Polonica, 92, 29-40.

Birkenmajer K., 1988. Exotic Andrusov Ridge: its role in plate-tectonic evolution of the West Carpathian Foldbelt. Studia Geologica Polonica, 91, 7-37.

Birkenmajer, K., 2006. Przełom Dunajca w Pieninach - fenomen geologiczny. Pieniny - Przyroda i Człowiek, 9, 9-22.

Birkenmajer K. \& Gedl P., 2017. The Grajcarek Succession (Lower Jurassic-mid Paleocene) in the Pieniny Klippen Belt, West Carpathians: a stratigraphic synthesis. Annales Societatis Geologorum Poloniae, 87, 55-88.

Birkenmajer K. \& Jednorowska A., 1984. Stratygrafia górnej kredy płaszczowiny pienińskiej okolic Sromowiec Niżnych w Pieninach. Studia Geologica Polonica, 83, 25-50.

Birkenmajer K. \& Jednorowska A., 1987. Late Cretaceous foraminiferal biostratigraphy of the Pieniny Klippen Belt (Carpathians, Poland). Studia Geologica Polonica, 92, 7-28.

Birkenmajer K. \& Oszczypko N., 1989. Cretaceous and Paleogene lithostratigraphic units of the Magura Nappe, Krynica Subunit, Carpathians. Rocznik Polskiego Towarzystwa Geologicznego, 59, 145-181.

Birkenmajer K. \& Pécskay Z. 1999. K-Ar dating of the Miocene andesite intrusions, Pieniny Mts. Bulletin of the Polish Academy of Sciences, Earth Sciences, 47, 155-169.
Birkenmajer K., Bąk M. \& Bąk K., 2001. Stop C5.3 - Sromowce Niżne - Trzy Korony Mt. [in:] Birkenmajer K. \& Krobicki M. (eds.), $12^{\text {th }}$ meeting of the Association of European Geological Societies; 10-15 September 2001, Kraków: Carpathian palaeogeography and geodynamics: a ultidisciplinary approach; field trip guide, Polish Geological Institute, Kraków, 146-150.

Chowaniec J. \& Kępińska B., 2003. Podhale geothermal system - selected issues. [in:] Golonka J. \& Lewandowski M. (eds.), Geology, geophysics, geothermics and deep structure of the West Carpathians and their basement, Publications of the Institute of Geophysics, Polish Academy of Sciences, 28 (363), IG PAN, Warszawa, 13-23.

Chrustek M., Golonka J., Janeczko A. \& Stachyrak F., 2005. Geological characterisation of the Krynica Subunit in the vicinity of Krościenko on the Dunajec river (Magura Nappe, Outer Flysch Carpathians). Geologia - kwartalnik Akademii Górniczo-Hutniczej im. Stanisława Staszica, 31, 1, 127-144.

Chrustek M. \& Golonka J., 2005.Carpathian tectonics in the making - deformations and earthquakes in the Stare Bystre area (southern Poland). [in:] Doktor M. \& Waśkowska-Oliwa A. (eds.), Geotourism - new dimensions in XXI century tourism and chances for future development: $2^{\text {nd }}$ International Conference GEOTOUR 2005: 22-24 September 2005, Kraków, Poland, University of Science and Technology AGH, Faculty of Geology, Geophysics and Environmental Protection, Kraków, 16-18.

Cieszkowski M., Golonka J., Krobicki M., Ślączka A., Oszczypko N., Waśkowska A. \& Wendorff M., 2009. The Northern Carpathians plate tectonic evolutionary stages and origin of olistoliths and olistostromes. Geodinamica Acta, 22, 101-126.

Csontos L. \& Vörös A., 2004. Mesozoic plate tectonic reconstruction of the Carpathian region. Palaeogeography, Palaeoclimatology, Palaeoecology, 210, 1-56.

Golonka, J., 2005. Mesozoic plate tectonics of the Inner Carpathians - rotational approach. Geolines, 19, 42-43.

Golonka J. \& Krobicki M., 2004. Jurassic paleogeography of the Pieniny and Outer Carpathian basins. Rivista Italiana di Paleontologia e Stratigrafia, 110, 5-14.

Golonka J. \& Krobicki M., 2007. Dunajec River rafting as one of the most important geotouristic object of the future trans-bordering PIENINY Geopark. Spływ Dunajcem jako jeden z najważniejszych obiektów geoturystycznych przyszłego, transgranicznego Geoparku PIENINY. Geoturystyka. Geotourism, 3(10), 29-44.

Golonka J. \& Rączkowski W., 1984a. Objaśnienia do Szczegółowej mapy geologicznej Polski. Arkusz Piwniczna. Instytut Geologiczny, Wydawnictwa Geologiczne, Warszawa.

Golonka J. \& Rączkowski W., 1984b. Szczegółowa mapa geologiczna Polski 1:50000. Arkusz Piwniczna. Instytut Geologiczny, Wydawnictwa Geologiczne, Warszawa.

Golonka J. \& Sikora W., 1981. Microfacies of the Jurassic and Lower Cretaceous sedimentarily thinned deposits of the Pieniny Klippen Belt in Poland. Biuletyn Instytutu Geologicznego, 31, 7-37.

Golonka J. \& Waśkowska A., 2014. Paleogene of the Magura Nappe adjacent to the Pieniny Klippen Belt between Szczawnica and Krościenko (Outer Carpathians, Poland). Geology, Geophysics \& Environment, 40, 4, 359-376. 
Golonka J., Aleksandrowski P., Aubrecht R., Chowaniec J, Chrustek M., Cieszkowski M., Florek R., Gawęda A., Jarosiński M., Kępińska B., Krobicki M., Lefeld J., Lewandowski M., Marko F., Michalik M., Oszczypko N., Picha F., Potfaj M., Słaby E., Ślączka A., Stefaniuk M., Uchman A. \& Żelaźniewicz A., 2005. Orava Deep Drilling Project and the Post Paleogene tectonics of the Carpathians. Annales Societatis Geologorum Poloniae, 75, 211-248.

Golonka J., Gahagan L., Krobicki M., Marko F., Oszczypko N. \& Ślaczka A., 2006a. Plate Tectonic Evolution and Paleogeography of the Circum-Carpathian Region. [in:] Golonka J. \& Picha F. (eds.), The Carpathians and their foreland: geology and hydrocarbon resources, American Association of Petroleum Geologists Memoir, 84, AAPG, 11-46.

Golonka J., Krobicki M., Oszczypko N. \& Salata D., 2006b. Stop 7. Krościenko-Zawiasy Klippe-Contact Zone between the Pieniny Klippen Belt and the Magura Nappe. Geolines, 20, 182-183.

Golonka J., Pietsch K. \& Marzec P., 2011. Structure and plate tectonic evolution of the northern Outer Carpathians. [in:] Closson D. (ed.), Tectonics, InTech, Rijeka, Croatia, 65-92.

Golonka J., Krobicki M., Waśkowska A., Cieszkowski M. \& Ślaczka A., 2015. Olistostromes of the Pieniny Klippen Belt, Northern Carpathians. Geological Magazine, 152, $2,269-286$

Golonka J., Krobicki M., Waśkowska A., Cieszkowski M. \& Ślączka A., 2017. Reply. Discussion of 'Olistostromes of the Pieniny Klippen Belt, Northern Carpathians'. Geological Magazine, 154, 193-200.

Golonka J., Pietsch K. \& Marzec P., 2018. North European Platform suture zone in Poland. Geology, Geophysics \& Environment, 44, 1, 5-16.

Guterch B., Lewandowska-Marciniak H. \& Niewiadomski J., 2005. Earthquakes recorded in Poland along the Pieniny Klippen Belt, Western Carpathians. Acta Geophysica Polonica, 53, 1, 27-45.

Horwitz K., 1963. Budowa geologiczna Pienin: Ludwik Horwitz: przygot. do dr. i opatrzył przypisami Krzysztof Birkenmajer. Prace - Instytut Geologiczny, 38, Wydawnictwo Geologiczne, Warszawa.

Hrušecký I., Plašienka D. \& Pospíšil L., 2006. Identification of the North European Platform below the Eastern Part of the Western Carpathian Flysch Belt. [in:] Golonka J. \& Picha F. (eds.), The Carpathians and their foreland: Geology and hydrocarbon resources, American Association of Petroleum Geologists Memoir, 84, AAPG, 717-727.

Jurewicz E., 1994. Structural analysis of the Pieniny Klippen Belt at Jaworki, Carpathians, Poland. Studia Geologica Polonica, 106, 7-87.

Jurewicz E., 1997. The contact between the Pieniny Klippen Belt and Magura Unit (the Małe Pieniny Mts.). Geological Quarterly, 41, 315-326.

Jurewicz E., 2005. Geodynamic evolution of the Tatra Mts. and the Pieniny Klippen Belt (Western Carpathians): problems and comments. Acta Geologica Polonica, 55, 295-338.

Jurewicz E., 2018. The Šariš Transitional Zone, revealing interactions between Pieniny Klippen Belt, Outer Carpathians and European platform. Swiss Journal of Geosciences. DOI: 10.1007/s00015-017-0297-9.
Jurewicz E. \& Nejbert K., 2005. Geotectonic position of the so-called "Pieniny Mts. andesites". Mineralogical Society of Poland - Special Papers, 25, 179-183.

Kováč M., Nagymarosy A., Oszczypko N., Ślączka A., Csontos L., Marunteanu M., Matenco L. \& Márton M., 1998. Palinspastic reconstruction of the Carpathian-Pannonian region during the Miocene. [in:] Rakús M. (ed.), Geodynamic development of the Western Carpathians, Geological Survey of Slovac Republic, Bratislava, Dionýz Štúr Publishers, 189-217.

Książkiewicz M., 1977. The tectonics of the Carpathians. [in:] Pożaryski W. (ed.), Geology of Poland. Vol. 4: Tectonics, Wydawnictwa Geologiczne, Warszawa, 476-618.

Kulka A., Rączkowski W., Żytko K. \& Paul Z., 1985. Szczegótowa mapa geologiczna Polski. 1:50 000. Arkusz Szczawnica-Krościenko. Państwowy Instytut Geologiczny, Wydawnictwa Geologiczne, Warszawa.

Marko F., Andriessen P.A.M., Tomek Č., Bezák V., Fojtíková L., Bošanský M., Piovarči M., Reichwalder P., 2017.Carpathian Shear Corridor - a strike-slip boundary of an extruded crustal segment. Tectonophysics, 703-704, 119-134.

Márton E., Grabowski J., Plašienka D., Túnyi I., Krobicki M., Haas J. \& Pethe M., 2013. New paleomagnetic results from the Upper Cretaceous red marls of the Pieniny Klippen Belt, Western Carpathians: Evidence for general CCW rotation and implications for the origin of the structural arc formation. Tectonophysics, 592, 1-13.

Márton E., Mastella L. \& Tokarski A.K., 1999. Large counterclockwise rotation of the Inner West Carpathian Paleogene Flysch - evidence from paleomagnetic investigation of the Podhale Flysch (Poland). Physics and Chemistry of the Earth. Part A, 24, 8, 645-649.

Márton E., Tokarski A.K. \& Halász D., 2004. Late Miocene counter-clockwise rotation of the Pieniny andesites at the contact of the Inner and Outer Carpathians. Geologica Carpathica, 55, 411-419.

Mišík M., 1994. The Czorsztyn submarine ridge (Jurassic-Lower Cretaceous, Pieniny Klippen Belt): an example of a pelagic swell. Mitteillungen der Österreichische Geologische Gesselschaft, 86, 133-140.

Nejbert K., Jurewicz E. \& Macdonald R. 2012. Potassium-rich rocks in the Western Outer Carpathians: magmagenesis in transitional zone between European Plate and the Carpathian-Pannonian regions. Lithos, 146-147, 34-47.

Nemčok M., 1980. Non-traditional view of East-Slovakian Klippen Belt. Geologický Zbornik Geologica Carpathica, 31, 563-568.

Nemčok M. \& Nemčok J., 1994. Late Cretaceous deformation of the Pieniny Klippen Belt, West Carpathians. Tectonophysics, 239, 81-109.

Neumayr M., 1871. Jurastudien. Der penninische Klippenzug. Jahrbuch der Kaiserlich-Königlichen Geologischen Reichanstalt, 21, 451-536.

Oszczypko N. \& Oszczypko-Clowes M., 2010. The Paleogene and Early Neogene stratigraphy of the Beskid Sądecki Range and L'ubovnianska Vrchovina (Magura Nappe, Western Carpathians). Acta Geologica Polonica, $60,317-348$.

Oszczypko N., Golonka J., Cieszkowski M., Krobicki M., Oszczypko-Clowes M. \& Salata D., 2006. Conference excursion 2: Late Cretaceous-Neogene evolution of the Polish Carpathians. Geolines, 20, 165-186. 
Oszczypko N., Slączka A., Oszczypko-Clowes A., Olszewska B., 2015. Where was the Magura Ocean? Acta Geologica Polonica, 65, 319-344.

Pieńkowski G., Schudack M. E., Bosák P., Enay R., Feldman-Olszewska A., Golonka J., Gutowski J., Herngreen G.F.W., Jordan P., Krobicki M., Lathuiliere B., Leinfelder R.R., Michalík J., Mönnig E., Noe-Nygaard N., Pálfy J., Pin A., Rasser M.W., Reisdorf A.G., Schmid D.U., Schweigert G., Surlyk F., Wetzel A. \& Wong T.E., 2008. Jurassic. [in:] McCann T. (ed.), The Geology of Central Europe. Volume 2: Mesozoic and Cenozoic, Geological Society, London, 823-922.

Plašienka D., 2012. Jurassic syn-rift and Cretaceous synorogenic,coarse-grained deposits related to opening and closure of the Vahic (South Penninic) Ocean in the Western Carpathians - an overview. Geological Quarter$l y, 56,601-28$.

Potfaj M., 1997. Relation of the Klippen belt and the Flysch zone in the territory of western Slovakia. [in:] Plašienka D., Hók j. Vozar J. \& Elečko M. (eds.), Alpine evolution of the Western Carpathians and related areas, Dionyz Stur Pablishers, Bratislava, 119-125.

Ratschbacher L., Frisch W., Linzer H.G., Sperner B., Meschede M., Decker K., Nemčok M., Nemčok J. \& Grygar R., 1993. The Pieniny Klippen Belt in the western Carpathians of northeastern Slovakia: structural evidence for transpression. Tectonophysics, 226, 471-483.
Sikora W., 1962. New data on the geology of the Pieniny Klippen Belt. Bulletin of the Polish Academy of Sciences, Earth Sciences, 10, 203-211.

Sikora W., 1971. Esquisse de la tectogénèse de la zone des Klippes des Pieniny en Pologne d'après de nouvelles données géologiques. Rocznik Polskiego Towarzystwa Geologicznego, 4, 221-239.

Vanko J., 1988. Mapa recentných vertikálnych pohybov Západných Karpát na Slovensku ore epochu 1952-1977. Geodetický a kartografický obzor, Bratislava, 34/76, 216-222.

Vass D., 1998. Neogene geodynamic development of the Carpathian arc and associated basins. [in:] Rakús M. (ed.), Geodynamic development of the Western Carpathians, Geological Survey of Slovac Republic, Bratislava, Dionýz Štúr Publishers, 155-158.

Wierzbowski A., Aubrecht R., Golonka J., Gutowski J., Krobicki M., Matyja B.A, Pieńkowski G. \& Uchman A. (eds.), 2006. Jurassic of Poland and adjacent Slovakian Carpathians: Field Trip Guidebook of 7th International Congress on the Jurasic Sytem, Poland, Kraków, September 6-18, 2006, Polish Geological Institute, 3-235.

Zuchiewicz W., Tokarski, A.K., Jarosiński M. \& Márton E., 2002. Late Miocene to present day structural development of the Polish segment of the Outer Carpathians. EGU Stephen Mueller Special Publication Series, 3, 185-2002. 